\title{
TRAVELLING INTO THE OTHER'S WORLD: SOUTH AFRICAN PRE- SERVICE TEACHER EDUCATION STUDENTS' CONSTRUCTION OF DIFFERENCE, BELONGING AND IDENTITY
}

\section{Gachago}

Centre for Innovative Educational Technology

Cape Peninsula University of Technology

Cape Town, South Africa

e-mail: gachagod@cput.ac.za

\section{Bozalek}

Directorate of Teaching and Learning

University of the Western Cape

Cape Town, South Africa

e-mail: vbozalek@uwc.ac.za

\section{Ng'ambi}

School of Education

University of Cape Town

Cape Town, South Africa

e-mail: dick.ngambi@uct.ac.za

\section{ABSTRACT}

Against the backdrop of continuing racism - both overt and subtle - in South Africa's classrooms, this article describes one lecturer's attempt at facilitating conversations around race relations in South Africa with nine pre-service student educators. Using Bamberg's (2012) positioning analysis to analyse how students constructed stories of difference, belonging and identity it transpired that students tended to position themselves first and foremost along racial lines, revealing their experiences of continuing academic and social segregation. Although students expressed a desire to overcome these divides, they struggled to visualise a world where black and white students could engage beyond their comfort zones, moving beyond the narratives with which they grow up. Lugones' (1987) concept of world-travelling and her suggestion that world travelling might be more difficult for those who are at most ease in their lives, was useful to unpack and understand the different roles students performed. Students' stories also showed the importance of destabilising dominant understandings of subjectivity, by allowing the emergence of fragmented narratives in difficult conversations. Recommendations of how to use narratives to facilitate students' world travelling include the emphasis on intersectionality, fluidity and complexity in students' stories but also discuss the challenges when facilitating such a process and the importance of self-reflexivity on the part of the facilitator. 
Keywords: narratives, small stories, identity, difference, race, world travelling, intersectionality, South Africa, Higher Education

\section{INTRODUCTION}

Since 1994, South African Higher Education (HE) has undergone major transformations, driven by the twin imperatives of racial transformation and pressures for efficiency (Department of Education 1997; 2001). However, research into the progress of transformation, such as the 2008 Ministerial Committee into Transformation and Social Cohesion in Higher Education (Soudien et al. 2008), draws a dire picture of the state of South African HE, confirming the pervasiveness of race and racism in the lives of educators and students. The ongoing student protests started in 2015 at the University of Cape Town around the removal of the Rhodes statue - a symbol of colonial oppression, the legacy of apartheid and lack of transformation - are a powerful reminder of the discontent and alienation that black students and staff continue to experience (Hodes 2015).

In the literature, one of the reasons given for the continuation of open and subtle racism in the classroom is learners' lack of social engagement across difference, and the resulting deepseated, unquestioned assumptions and beliefs that we have about the "Other" Zembylas 2003; Jansen 2009; Bozalek 2011). The 2012 South African reconciliation barometer survey showed that youth's primary association is still language, followed by ethnicity and race. Forty-four per cent of young South Africans rarely or never speak to someone of another race (Lefko-Everett 2012). Socio-economic background is a key determinant of social interaction across racial lines: income is perceived as the strongest divider in this country today. Studies show that even in racially integrated classrooms, students tend to identify strongly with their racial background and actively construct identities in opposition to each other (Pattman 2010; Rohleder et al. 2008; Bozalek 2011; Swartz et al. 2009).

Jansen (2009) calls these - often unconscious - assumptions and beliefs about others, "indirect knowledge", passed on from one generation to the next. This knowledge not only impacts on our choice and negotiations of social engagements: it is also "troubled", as it is steeped in discourses of power and privilege and draws out the "worst racial stereotypes, prejudices and aggressions among students” (Jansen 2004, 121). It is knowledge that makes it possible for five white students to racially insult and assault a black woman outside a Capetonian night club, or for a raging white swimming coach to attack a black woman because he assumed she was a "prostitute", for another student to urinate on the head of a black taxi driver from the balcony of night club in Cape Town's Southern Suburbs (Thamm 2014).

Authors concerned with social justice in education, such as Jansen (2009) and Zembylas 
(2008; 2013) emphasise the importance for educators to develop pedagogical interventions that would allow a recognition and disruption of this troubled knowledge. Zembylas (2013), for example, notes that there is an urgent need for pedagogical interventions that address this knowledge, which, as he argues, is not only troubled but also deeply defensive and can evoke strong emotions in students, such as guilt, defensiveness and anger. He suggests that these interventions should be characterised by recognition of mutual vulnerability and unequal power relationships, and a critical look at the emotions that accompany these engagements. In the context of South Africa, this would mean starting an honest and candid engagement with the legacies of apartheid. This must go beyond Nelson Mandela's attempt at nation building through a rainbow nation discourse, focusing on sameness and avoiding potentially uncomfortable conversations around issues of race, privilege and systemic oppression (Gachago and Ngoasheng 2016).

This article draws from a larger study, which aimed to explore the potential of digital storytelling as a tool to transform students' engagement across difference, by sharing personal stories but also creating a space for such difficult conversations. We have reflected on the potential and limitations of digital storytelling - both as a process and a product - as a socially just pedagogy elsewhere (see for example Gachago 2016; Gachago et al. 2015; Gachago 2015). This article specifically focuses on difficult conversations that happened during the process of creating a digital story. We were particularly interested in the small stories that students told each other in facilitated conversations during the workshop, and what we could learn from students' construction of identity, belonging and engagement with "Others” in this process. Framed by Lugones' concept of world travelling (1987) and theories of intersectionality (Yuval-Davis 2006; hooks 1994; 2000) this article explores what an analysis of these stories can tell us about students' understanding of race and privilege, the on-going challenges that we face when addressing race and privilege in the classroom, but also how some of their stories could be used as bridges into each others' worlds. The chapter thus contributes to an emerging field of research on pedagogical interventions that engage students in difficult conversations to create more socially just classrooms.

\section{CONTEXT: PERSONAL STORYTELLING, TEACHER EDUCATION AND FACILITATING DIFFICULT CONVERSATIONS}

One way of encountering and learning about the "Other" is through sharing personal stories. Storytelling has been long used as a pedagogical tool that allows diverse learners in the classroom to unearth lived experiences and to allow a more nuanced understanding of 
difference (Aveling 2001). The act of a sharing one's story not only leads to a better understanding of oneself, but also allows for connections to be established across difference through the sharing of one's vulnerability. Sharing personal stories may also help revealing the “narrative unconscious” (Freeman 2010), the indirect knowledge we grow up with.

The context of the chapter is the Faculty of Education and Social Sciences at a large university of technology in the Western Cape and is drawn from a larger study investigating digital stories in diverse classrooms (Gachago 2015). The digital storytelling project the larger study explored was introduced into the pre-service teacher training in order to allow students to reflect on their diverse backgrounds and to develop a heightened understanding of their own and their peers' social positioning vis-à-vis personal, institutional and systemic structures. The participants of the study volunteered as peer facilitators and attended a five-day, train-thetrainer digital storytelling workshop in August 2013, in which they were guided in the development of their digital stories (see Table 1). Each of these peer facilitators later supported a group of peers in the development of their digital stories. As students volunteered to be part of this study, we did not have any influence in the demographic make-up of the group. As can be seen in Table 1, students for example are predominantly African or White, with only one Coloured student. Also, they are predominantly female with English or IsiXhosa as their home language. In terms of religion, there is only one student from a Muslim background. As such the student sample is not representative of the class. This limitation will be discussed later in the article.

Daniela facilitated this train-the-trainer workshop but was only involved as observer in the course itself. Furthermore, she was not involved in any marking of the digital stories. It is important to reflect on her positionality in her interactions with the study participants as a white, middle class European woman. While her status as outsider allowed her to ask questions and address topics that insiders might feel uncomfortable to tackle, she also had to repeatedly recognise her limits in understanding her students' stories and acknowledge that her reading of the participants' stories would be impacted by Eurocentric thought and structures (Chaudry 2009). Frequent participant checks and the co-authoring of articles with a diverse group of colleagues were some of the measures put in place to mitigate against these risks.

Ethics clearance was sought and granted from the institution. Workshop participants gave informed consent to be part of this study. All names apart from Noni and Lauren's were changed to grant participants confidentiality. Lauren's and Noni's names remained unchanged with their permission - as their stories were analysed in more depth for the larger study including their digital stories and total anonymity was not possible in these cases. However, the implications 
of this were discussed repeatedly with the two participants including their right to withdraw from the study at any time.

Table 1: Study participants

\begin{tabular}{|l|c|c|c|c|c|}
\hline Student name & Gender & Race & Year of birth & Home language & Religion \\
\hline Full research participants \\
\hline Noni & Female & African & 1988 & isiXhosa & Christian \\
\hline Vuyelwa & Female & African & 1984 & isiXhosa & Christian \\
\hline Beatrice & Female & White & 1967 & English & Christian \\
\hline Lauren & Female & White & 1991 & English & Christian \\
\hline Nazma & Female & Coloured & 1991 & English & Muslim \\
\hline Michael & Male & White & 1987 & English & Christian \\
\hline Siyabonga & Male & African & 1985 & isiXhosa & Christian \\
\hline George & Male & African & 1980 & isiXhosa & Christian \\
\hline Rachel & Female & White & 1991 & English & Christian \\
\hline
\end{tabular}

Following other authors (Benmayor 2008; Coventry 2008; Oppermann 2008) who have expanded the typical three-day standard workshop process developed by the StoryCentre (Lambert 2013), various elements were added to this digital storytelling workshop to deepen students' stories. Students were for example encouraged to engage with critical readings around issues of difference such as race, gender, class in their own time beyond the workshop in an attempt to break the usual silence around these topics (Mazzei 2008). Authors such as Benmayor (2008), Bozalek et al. (2010) and Aveling (2006) argue that critical readings can beyond triggering memories and emotions - help students theorize their own stories against these readings: "personal experience becomes theorized, situated” (Benmayor 2008, 159). Benmayor suggests that putting personal narratives in dialogue with critical readings enhances students' understandings of what it means to theorise their own identities "from the flesh", by combining experiential, emotional learning with an intellectual analysis based on the reading of critical texts. Our hope was that by engaging with carefully selected articles students would be able to frame and set their stories in a larger socio-cultural and historical context, and further interrogate their own assumptions and beliefs (Bozalek and Carolissen 2012). For a list of the selected readings provided in the course see Gachago (2015).

\section{METHODOLOGY}

In this article we focus on the many stories students told alongside the development of their digital story, what Bamberg calls "small stories", feeding into the final digital story they create, the output of the digital storytelling process. In recent years, narrative inquiry's interest in the underlying structures of narratives has increased. Bamberg (2006) and Georgakopoulou 
(2006a), for example, argue that there has been too much emphasis on the content within narrative inquiry, and not enough on form and structure. They claim that, in general, narratives are used more or less as unmediated and transparent representations to establish how storytellers make sense of themselves in light of past events (Bamberg and Georgakopoulou 2008). By focusing on the "small stories" constructed in everyday, mundane situations, they offer an alternative to what they deem "idealizing and essentializing accounts that have tended to see narratives as authentic and uncontaminated accounts of self” (Georgakopoulou 2006b, 128). These stories are small both metaphorically and in the literal sense of being brief. They tend to "focus on the micro-, fleeting aspects of lived experience” (Bamberg and Georgakopoulou 2008, 378).

Bamberg and Georgakopoulou explore how identities are constructed in interaction, which is why some authors call this approach "narratives-in-interaction" (Bamberg 2006; Bamberg and Georgakopoulou 2008). Thus, the narrative is no longer just a means to an end, but the focus of analysis and the end in itself. Emphasizing the performative does not necessarily mean that identities are inauthentic but rather, as Kohler Riessman (2008) points out, “... that identities are situated and accomplished with an audience in mind”.

An important framing concept for the analysis of small stories, is “positioning”. There are three levels of positioning in the analysis of small stories (Barkhuizen 2009):

1. Level 1 asks questions on the content of the story and the characters, and how these characters relate to each other.

2. Level 2 asks questions on performative/interactional aspects of the story, on how the storyteller positions him or herself towards his or her audience

3. Level 3 looks at how the story is positioned vis-à-vis master narratives or hegemonic discourses (the context of the story).

For this study, we looked closely at the stories that students told during one check-in session at the beginning of day four of the workshop. In the session this study focuses on we discussed Sisonke Msimang's (2013) article on "The unfinished business of race and reconciliation in South Africa”. ${ }^{2}$ While this conversation was loosely facilitated - i.e. Daniela initiated the checkin and asked for feedback on the article - it took on a life on its own and became a turning point in the workshop. Students resorted to telling personal stories to make their points clear or to convey their experiences to their peers in response to each others' stories. The conversations were video recorded and transcribed. As part of the analysis process these small stories were 
extracted from the transcriptions and "polished" (Kohler Riessman 2008), to make them flow more easily, without losing the content of the stories. For this chapter we are most interested in level 2 positioning in the analysis of these small stories, i.e. how students constructed stories in response to each others' stories and how they positioned themselves in relation to each other in these stories.

\section{STORIES OF IDENTITY, BELONGING AND DIFFERENCE}

It is day four of the workshop. Students have shared their stories in story circles and are busy finalising their scripts and starting on collecting images and movie editing. It has been an emotionally tasking week, difficult topics have been approached, and painful stories have been shared. Students have grown closer. The atmosphere in the group is one of excitement, passion about their stories, but of the usual frustration at the slow pace of the movie making and fear that they won't be finished by day five for the final screening of the stories. The homework task for today was to read Sisonke Msimang’s 2013 article on “Our unfinished business: race and reconciliation in South Africa”, aimed at challenging students into a debate beyond the usual careful politeness or outright silence that characterises conversations around race relations in South Africa.

The first person to respond to the facilitator's prompt to reflect on the article, is Beatrice, a white, mature student, who lived through Apartheid. She tells a story about her unconscious social engagements, about power relations, employing black people, but not inviting them to her house socially, but also about the need to step out of her comfort zones, about the possibility of change.

\section{Story 1: Beatrice}

"The article speaks about blacks and whites still gathering only in their groups and not really visiting each other.

We claim to be friends with each other and yet we don't visit each other at home. (looking at Vuyelwa and Noni)

I actually reflected on that for quite a long time and I asked myself: when last did I ever entertain my black friends at home?

My daughter has plenty and she goes to a lot of them socially but I don't. (looking at the facilitator) Mind you, I don't even have a lot of white friends either.

So for me it's now to decide whether I could include my friends from a different race.

Not that I exclude them, it's just that (pause) I just never think about just opening your home ... I employ black people and they are in my home. 
But I don't ever think of visiting with them. (looking at the facilitator)

And it means then that I need to know that I need to step out of my little circle, my little comfort zone, and I need to reach out and invite my friends home and have a good visit.

I don’t know if I am just preoccupied ‘coz I like my solitude.

But it's definitely something that I need to work on, that I can work on because I am not against having black friends.

It's just that I never thought to just open my space, I don't open my space to a lot of people in my home. (looking at Vuyelwa and Noni)

I am in my home because that's my place of safety and that's where I like to be.

But I definitely can do something about it.”

Lauren, another white, though much younger student, adds to Beatrice’s story. She as well, refers to her "colour-blindness", to her being different, evoking her black friend, but also to the limits of this friendship, confined geographically to Johannesburg, and the lack of diversity in her life in Cape Town, the unconscious ease that makes her gravitate towards people who look like her. She talks about the fear of the unknown, in her case referring to cultural barriers when engaging with a person of a different race.

\section{Story 2: Lauren}

"I was saying to Rachel in the car this morning, (turning towards Rachel) 'one of my really good friends is black, she lives in Joburg. She comes to stay with me in the holidays you know. I don't see that she's black you know, we have been friends for so long. She's just like any of my other friends.'

But then Rachel said to me: 'how many other black friends do you have?'

And I sort of thought - she is kind of my only black friend. So it's not that I have like a wall up and I am thinking I don't wanna be friends with black people, because of that I don't even I suppose you know that side of it. But I just think automatically our brains are in tune with white people: let's go sit with them, white people, lets invite them over. And we are almost scared to break that cultural barrier of inviting another race into our home, of entertaining and letting them in, because we feel subconsciously this difference. And I think it's about getting through that and that's what the reconciliation is all about: (Beatrice nodding) it's not just about saying you are black and I am white. We can sit together and have a chat. It's about emotionally opening ourselves up and saying: 'we do have different backgrounds and different cultures but we can still get along' Just like I get along with a white person and be just as close you know, that's just what the article sort of spoke to me about."

Next to speak is Vuyelwa, who is trying to make her peers understand the difficulties of having friendships with "Others", pointing as well to the comfort of the known, shared experiences, a shared language, a shared accent. However, her story also points to the power dynamics ruling the classroom, the hegemonic standards of the English language, the importance of assimilating to the dominant culture, if one wants to fit in. 


\section{Story 3: Vuyelwa}

"If I want to be friends like with Beatrice, most of the time I have to try to act the way she's acting and speak the way she's speaking, because most of the times she's gonna say: 'Whoooo Vuyelwa, some of your words are sooo ... you can't pronounce some of the words like this.'

When I was at the college, there was one word that I used. I said: 'I must go and make my affidavit' and everyone was laughing at me (everyone laughing) you can't say that affidavit and I say like what? What am I supposed to say: affidavit (everyone laughing)? and I would say: 'nooo you want me to adapt to your way of speaking. This is my kind of way of speaking. I am a Xhosa, so am proud of it. So if I pronounce this word like this - that is my own kind of a way. So if you guys believe that am saying it wrongly, you can't judge me'."

Siyabonga, a black male student reinforces this point by relating a story from his past, also highlighting the hegemonic standards of beauty, the continuous aspirational power of whiteness that he experiences when travelling home.

\section{Story 4: Siyabonga}

"I remember when we were kids, if you just had had a haircut, then people would say: 'you look nice, you look like you know umlungu', which means you look like a white person, yeahh so there is still that thing on our minds that a white person is better.

I was home in January and then my nephew is 13 . He said: 'Yo, you know what,' he called me buti, 'you know what, buti, I want to go to school like you and I want to be rich like a white person'.

Like what is it with white people? Why do you want to be like white people?"

In this exchange the atmosphere in the room turns - playfulness and camaraderie turns into something more sober, uncomfortable and tense. Noni, another black female student tries to diffuse the tension, by moving from the personal to the systemic, to a broader socio-cultural and historical perspective of inequality in South Africa. She tells a story about a racist incident she experiences with a friend - trying to make her white peers understand that racism is not necessarily a "bad" personal trait, but an inherent consequence of growing up in a deeply unjust system, in this case the legacy of Bantu education during the years of Apartheid, transferred from one generation to the next.

\section{Story 5: Noni}

"One of these days, I was with a friend of mine. (looking at Nazma and Lauren). This other lady who works at campus at library at night, we were going to a Saint Peter's mall in Observatory. I don't know, what she did, but she was driving, and then this white man came up on the window 
and said: 'Ohhh you people can’t think ... what's wrong with you? why did you do that what not what not'.

And I thought: 'Wait, why can't she think?' I mean, yes, she, it's her brain and stuff, but why can't she think? Her parents got an education that discouraged thinking and her parents raised her! Whose fault is that? Is it really nobody's faults, is it really not YOUR fault it's not your fault. (addressing Lauren) Yes you know it's not our fault right here? But its someone's fault and it's not my people's fault, because someone forced laws and what not on them, so that they be like this.

And today when I can't think in class, when I can't raise my hand up and respond to whatever or participate in class, you are thinking, 'why can't they think'? Forgetting that I am being raised by the same person, who was taught not to think. And then I thought how we as South Africans are running away from the truth. (addressing Rachel). This is our truth in South Africa, there is like a huge wall between us. There are extremely privileged people and those people are white people most of the times, yes they're rich black people look ... but look at that: we are running away from talking about issues like this (pointing at images of life in informal settlements on the screen), where we, yes like Lauren was saying, we do mix, we do become friends with other races like, do we make meaningful relationships? We are running away from the fact the best schools in South Africa are still white schools. And then I thought: 'I don't want to tell this story, because I don't want to make people to feel uncomfortable'. But then we are talking about uncomfortable spaces the whole week, (Rachel nodding) and I am thinking: 'why should I run away from it'? (addressing Beatrice and Lauren). From the moment Beatrice opened the mouth, everybody was saying the same thing. How we all are brushing over this race issue of one race being privileged and the other race being less privileged.”

Noni’s story makes George, a usually quiet, mature, black male student speak out for the first time in this conversation. He challenges her notion of privilege based purely on race and adds class to the conversation:

\section{Story 6: George}

"I think the way you were brought up coming from a white family, coming from a black family ... The way you were brought up. Seeing other people who were more suffering than you and seeing that I get these clothes, it doesn't matter if they are like labels and stuff ... I am wearing these shoes .... This person doesn't have shoes, she goes to school on a bare foot, I think that is privilege to me. Eating three times a day and maybe that person eats once a day, I think that is also privilege.”

Rachel, a white young female, takes George’s story as an opportunity to speak out. During the workshop, Rachel was usually quiet but supportive of what students said. However, at this point in our conversations, she suddenly loses her composure and lashes at the facilitator, showing her anger and frustration at being misunderstood, unfairly treated, positioned within a space of privilege based on race which she can't relate to. She accepts her privilege, but links it to her upbringing in a caring, loving house, and not to her race: 


\section{Story 7: Rachel}

“And it's just that since Monday, we have been throwing the word privilege around and you made it seem like white people's privilege. (looking at facilitator). You are reading my story and you said: 'Ohhhh you are not bringing through that you are a white privileged person' and I said to you: 'Well not all white people [are privileged] ...'. My privilege was having love and praise and supportive parents. I am not privileged because I am white and not only white people are loved. So I wasn't privileged because I had a lot of money in my life ... That's not privilege. I was talking about it in my story. I was privileged because I had food, I had love, George was saying: 'I have clothes to wear every day'. So I think we have to define the term privilege that we are talking about here.”

This makes Vuyelwa step in in order to tell a very personal story about her upbringing, which again changes the atmosphere in the circle. Her story weaves the many themes brought up in the stories together: the hegemonic standards favouring whiteness in this country, the complex power relationships between "Madams and maids" in South Africa, her own understanding of privilege.

\section{Story 8: Vuyelwa}

"When I grew up with my grandmother, she used to work for a white person. (directed at facilitator, hands folded in front of chest). What fascinated me was, every time she comes back from work, she would come back with a bag in her hand. Having like breakfast and lunch and supper. (hands opening up). We felt privileged that we had to eat the white man's food. The type of food that wasn't there, we don't normally have it. We felt like: Ok. I am better ... in my house, we eat better than other person, because my grandmother brings this and that. But while she was sitting down, she will say: 'Yohhh I work my butt off, because this week the person who owns me said, I must wash all the windows and then next week I must do it again, and the following week I must do it again.'

That felt to me like ok, they are doing this to my grandmother ... who are they? The white people. So I felt like: Ok these people, how come they do not see that she's an old lady, whereby she works hard to get just a little sum of money? Just to have food on our table. Even though our parents are, my mother was scattered around and my half sister was on the other side of the house, and we had to sit there as grandchildren and cousins and all that stuff. But we shared that food - we felt like ok they are privileged ... Like they had nice food and all those stuff. So I think I am being privileged is a big word, it is a big word. Because there are some of things that we experienced, that are not the same as them. And some of things that white people did experience, are not the same as ours. The experience is not the same.

They might feel: Ok, I feel they might like, I feel less privileged, because I didn't get that and that and that. But the black person didn't get the opportunity to experience life like this and that and that.

But on our side we feel like: Ok, they get much privilege, because my mother was looking after her, and then at night she got tired at home and she won't have time to spend with me. Most of my time that she was supposed to be spent with me, she spent it with them. But when she, when she got home, she couldn't do my homework, she couldn't, she couldn't cook for us or maybe if she did, she look tired while she was doing it. So I think being privileged is a very big word. (Noni: yes, $\mathrm{mmm}$...).” 
Her story leaves the group in a deeply touched, thoughtful, less defensive mode. We wrap the session up quickly, at a loss of what to add to her story and students continue working on their individual stories.

\section{DISCUSSION OF STUDENTS' STORIES - ON EASE, DISCOMFORT, PLAYFULNESS AND THE COMPLEX BUSINESS OF TRAVELLING INTO EACH OTHERS' WORLDS}

Georgakopoulou (2006b, 4) argues that “small stories' interactional features were both constituted by and constituting [participants'] sites of engagement as culturally shaped (and in this case, gendered and constraining) liminal spaces”. The stories told in the conversation and represented in this article could be read as similarly shaped and constrained by race, but also by gender, age and class.

The first group association that students consistently pointed out was the one of race. Although the article that was used as trigger for this conversation, engaged and challenged the status of race relations in South Africa, the ease and comfort students used words such as white, black and coloured, to identify themselves and each other, their acceptance of the arguments in the article, points to the normative nature of this association and the continuing power of race to position people in South Africa. Both public spaces, such as their classrooms, and private spaces, such as their homes, were perceived as distinctly segregated along racial lines.

As a collective, these stories students painted an all-too-familiar picture of South African society today. Dominant narratives emerged, such as social segregation, white privilege, internal oppression and hegemonic standards. Well known roles were taken: on one hand we had black students pointing out injustices, trying to make their white peers understand what intergenerational oppression and privilege means, a sometimes playful, sometimes harrowing consciousness-raising to help their white peers understand their experience. On the other hand we found white students' discomfort around the topic of race (Mazzei 2008), reacting defensively, refusing to take on complicity or responsibility for past injustices. The anger displayed by Rachel shows the difficulties of young white South Africans to engage with the complex emotions passed on from the past when it comes to the issue of privilege. While her anger and frustration seemed to resonate in her peers, failure to acknowledge continued systemic oppression and our complicity in it, is dangerous as it denies black people their pain. Describing this non-acknowledged privilege by white students, Tronto (1993) defines "privileged irresponsibility" as the ways the dominant group fails to acknowledge the benefits they directly or indirectly still continue to derive, thus maintaining their taken-for-granted 
positions of privilege (Zembylas, Bozalek, and Shefer 2014). DiAngelo (2011) would frame white students’ responses as “white fragility”; Zembylas $(2013,511)$ would identify this as sentimentality, a form of self-victimization, which he defines as

“... emotional resistance of those students who feel they are victims themselves (e.g., students who are marginalized at various degrees) and entails feelings of indignation, self-pity, and resentment for paying attention to others' suffering."

Lugones' (1987) “world-travelling” is a useful concept when thinking about engaging students across difference and allows us a more nuanced view of students' interactions in these conversations, beyond the binaries of white fragility and black pain. Lugones writes from an experience of an outsider, a black Latino woman among a White/Anglo organisation of life in the US. Emphasising a lack of connection and denial of our entanglement with the "Other", which leaves us "incomplete and unreal” $(1987,8)$, she suggests that for us to become whole again we must move beyond our independence of, our indifference towards our "Other”. We need to rediscover our entanglements, our interconnectedness, our love for this "Other”, as she explains: "travelling to each other's 'worlds' would enable us to be through loving each other" $(1987,8)$. This world travelling becomes a wilful exercise that constitutes cross-cultural and cross-racial loving. She defines world travelling as "skillful, creative, rich, enriching and, given certain circumstances, as a loving way of being and living” $(1978,3)$. Seeing with loving eyes would mean travelling into somebody else's world, experiencing somebody else's world, not in her place, but with or next to her. This is crucial, rather than the common-place notion of stepping into somebody else's shoes, we acknowledge that we will never be the same and we can never fully understand the "Other”, we will be always differently positioned from the "Other".

Vuyelwa's story shows our entanglement, our interconnectedness beautifully: because her grandmother and mother had to work for white people, she felt deprived of the care and attention she should have gotten herself from her mother. This is a great example of how personal and structural responsibility are linked (Young 2011). While her mother did not look after Lauren or Rachel, it is likely that Lauren and Rachel were looked after by a mother with a similar story to the one Vuyelwa told. We are all entangled and it is only through this entanglement that we can understand our shared responsibility for personal and structural injustices - in Lugones' words, the act of telling this story of entanglement was an act of love on the part of Vuyelwa.

There are many worlds that we inhabit and we are more or less comfortable or at ease in 
these worlds. Lugones links ease and comfort in a world to: being a fluent speaker in a "world", knowing all the words and moves, and being confident; being normatively happy, agreeing with all norms; being humanly bonded and being with those one loves; and having a shared daily history. She also suggests that such world travelling might be more difficult for those who are most at ease and comfortable in their lives, their worlds. She attributes an unconscious arrogance to these people that are at "maximum ease" in their world. It is important to note that while world travelling might be difficult for those feeling too comfortable in their lives, for outsiders to the mainstream practicing world-travelling is a necessity. This echoes to DuBois' (1903) concept of "black double consciousness": the necessity of seeing oneself through the eyes of “Other” as a survival technique long practiced by oppressed groups.

World-travelling needs what Lugones calls "playfulness", which involves being open to being surprised, taking risks, allowing oneself to be a fool, allowing oneself to re-imagine new worlds, without fear of uncertainties or an absence of rules. Ford $(2004,341)$ interprets such playfulness as necessary “... to unsettle [...] a hegemonic desire for frames of reference about a common world”. This playfulness is only accessible to us, if we feel comfortable or at ease in at least one of the worlds we inhabit and world travelling will be easier if we start from a world where we feel at ease (unless as discussed above we feel at maximum ease - not uncomfortable in any of the worlds we inhabit).

In some of the student stories, such as Vuyelwas' account of her peers' teasing her English pronunciation, challenging hegemonic values and discourses, this playfulness is evident. Also Noni's attempt to make her white peers understand, that she was not "pointing fingers", not trying to find "who is responsible”, but simply asking for a recognition and awareness of white privilege and the systemic inequalities that still haunt South Africa, can be seen as a bridge building activity - an attempt to invite her peers into her world. Following Lugones' argument this could mean that both Vuyelwa and Noni, although they - as their narratives show - often inhabit worlds they don't feel at ease in, were able to open up their own worlds and invite others in through their stories in both playful and world bridging ways in the context of the workshop. Through their stories they force their peers out of the unconscious "arrogant perception" (Lugones 1987, 4) that comes with being at ease and usually as Lugones argues, ignore, render invisible, stereotype and leave untouched, the others upon whom their perceptions of the world does not depend. Noni and Vuyelwa's stories force us to at least take a glance into their worlds.

Beatrice's story is interesting in this context. Contrary to Rachel and Lauren, she did not immediately reject responsibility for her lack of diverse social engagements, but listening to her peers' stories and engaging with the critical reading seemed to have started a self-reflective 
process, that led to raised awareness of her need to break out of comfort zones, although her story was still fraught with self-justifications and apologies for her (non)actions. In this study, based in a South African Higher Education undergraduate classroom, Lugones' normative world would favour white, male, middle-class, heterosexual, christian and young students would make these students feel most at ease. Returning to Beatrice, one could argue, that her position as a mature student, slightly on the margins of the normative space of this classroom, made it easier for her to accept responsibility, to open herself up for other stories and other worlds, a prerequisite for world-travelling.

Would it help to disrupt more wilfully students' understanding of hegemonic norms and standards? What is the role of the facilitator in these spaces? If ease and comfort is attributed to those who are positioned within normative standards, how could one make this space less comfortable for them? Would this ease and comfort be challenged when norms and standards are challenged? Ivits (2009) reminds us of the importance to destabilise dominant understandings of subjectivity, to disrupt an understanding of an autonomous, coherent subject, by allowing the emergence of fragmented narratives in uncomfortable conversations. What could be observed in this workshop is that when students opened up, made themselves vulnerable, when they took risks and shifted the lens from race to other social identifiers such as gender, age and class, interesting ruptures happened and new connections were formed.

Through this lens, Rachel's story, for example, told from her position as white working class background, openly challenging the facilitator, could be also be seen as an act of risktaking, of breaking her silence around race and privilege, which disrupted established power dynamics in the classroom between teacher and students. George' story, told from a slightly more privileged background than his black peers, could be interpreted as a challenge to dominant discourses around race. In both stories an intersectionality of race, gender and class was surfaced, potentially allowing for connections between students that a limited view on race had previously blocked. Beatrice's stories, told from the perspective of a mature white woman, struggling in a male dominated world, resonated with Vuyelwa, showing the intersectionality of race, age and gender. Intersectionality allows for the recognition that social position is based on multiple social signifiers such as race, colour, age, social class, ethnicity and culture. YuvalDavis (2006) speaks of intersectionality as the idea that social location must be constructed along multiple axes of difference, which constitute each other. Intersectionality can help us understand differentiated oppression and allows a more nuanced picture in the context of Lugones' world-travelling: comfort and discomfort are based on many different factors beyond race, such as gender, class, language, age, sexuality or religion. 
What is missing from these conversations though, is the coloured voice. The one coloured student in the group remained silent throughout this conversation. While a lot has been written about white silences in raced conversation (see for example Mazzei 2008), there is a dearth of literature around the coloured (non)engagement. Ngoasheng and Gachago (2017) have reflected on the challenges of addressing the legacy of differentiated experiences of oppression during Apartheid in South African classrooms elsewhere and we would like to note that had there been stronger coloured voices in the group, the way the narratives would have been constructed and the power dynamics in the group would certainly have been different.

\section{CONCLUSIONS}

This article reflected on the small stories students told as a "by-product" of a digital storytelling project and what these stories could tell us about how students positioned themselves and their peers in post-Apartheid South Africa. The daily check-in sessions at the beginning of each workshop day, in which students reflected on set critical texts, became spaces for students to unpack and explore sensitive issues such as race and privilege. Authors such as Freeth (2013) or Gobodo-Madikizela (2008) argue that particularly in South Africa these spaces are essential to overcome racial divides and challenge some of the indirect knowledge our students bring to the classroom. These conversations not only acted as conduits for these narratives to emerge, but also created bridges to allow students to travel into each others' worlds and impacted strongly on the final output of this process, students' digital stories. The conversations also highlighted the importance of intersectionality when addressing identity in post-Apartheid South Africa. These findings are not necessarily new, but are an important reminder of the ongoing need of addressing race and privilege in South African classroom while also showing the challenges when doing so. Framing the analysis of students' stories with Lugones' concept of world travelling gave us a more nuanced understanding of students' diverse roles in this endeavour.

However, recognising and challenging essentialising social identifiers, foregrounding pluralistic subjectivities that are forever changing and shifting, to allow connections to happen through the travelling into each other's worlds, needs a high level of facilitation skills on the part of the lecturer. Without careful guidance difficult conversations such as these could easily turn into students' pitching their own pain against each other, reinforcing existing power dynamics, beliefs and assumptions in the classroom. As a next step then one would have to look at the facilitator's responses and attempts at holding a space that can both reveal the "narrative unconscious", the assumptions and beliefs emerging in our narratives, and allow students to 
feel safe enough to be "playful” and take risks in order to travel into each other's worlds. How do we as facilitators of these processes engage and respond to our students' stories with a loving gaze, with wonder and surprise rather than with judgement and contempt while at the same time for example calling out white fragility to keep the space safe for people of colour? Ford (2004) asks us to take students' resistance as encouragement to look at our own arrogant perceptions. Facilitating the telling of personal narratives, which have the power to both affirm and disrupt individual and collective subjectivities, to create a space where world-travelling might be slightly more possible, needs facilitation skills, experience and continuous self-reflexivity on the part of the facilitator and remains a critical and ongoing project for us as educators concerned with social justice in education.

\section{NOTES}

1. We use "Other" in capital letters and inverted comma, to foreground the socially and discursively constructed nature of the other - a "distant other" who in this case not only doesn't look like us but to whom we are always in some ways differently positioned in relation to power and privilege. This "Other" is always positioned as either more or less privileged than us and our relationship is always based on an unequal power distribution.

2. http://www.dailymaverick.co.za/opinionista/2013-06-12-our-unfinished-business-race-andreconciliation/

\section{REFERENCES}

Aveling, Nado. 2001. “Where do you come from?”: Critical storytelling as a teaching strategy within the context of teacher education. Discourse: Studies in the Cultural Politics of Education 22(1): 35-48. doi:10.1080/0159630012003974.

Aveling, Nado. 2006. "Hacking at our very roots": Rearticulating white racial identity within the context of teacher education. Race Ethnicity and Education 9(3): 261-274. doi:10.1080/13613320600807576.

Bamberg, Michael. 2006. Stories: Big or small - Why do we care? Narrative Inquiry 16(1): 139-147.

Bamberg, Michael. 2012. Narrative practice and identity navigation. In Varieties of narrative analysis, ed. James A. Holstein and Jaber F. Gubrium, 99-124. Los Angeles, London, New Delhi, Singapore, Washington DC: Sage.

Bamberg, Michael and Alexandra Georgakopoulou. 2008. Small stories as a new perspective in narrative and identity analysis. Text \& Talk 28(3): 377-396. doi:10.1515/TEXT.2008.018.

Barkhuizen, Gary. 2009. An extended positioning analysis of a pre-service teacher's better life small story. Applied Linguistics 31(2): 282-300. doi:10.1093/applin/amp027.

Benmayor, Rina. 2008. Digital storytelling as a signature pedagogy for the new humanities. Arts and Humanities in Higher Education 7: 188-204. http://doi.org/10.1177/1474022208

Boler, Megan and Michalinos Zembylas. 2003. Discomforting truths: The emotional terrain of understanding difference. In Pedagogies of difference: Rethinking education for social change, ed. P. Trifonas, 110-136. New York: RoutledgeFalmer.

Bozalek, V. 2011. Acknowledging privilege through encounters with difference: Participatory learning and action techniques for decolonising methodologies in southern contexts. International Journal of Social Research Methodology 14(6): 469-484. 
Bozalek, V. and Ronelle Carolissen. 2012. Designing the project: Theoretical approaches. In Community, self and identity: Educating South African university students for citizenship, ed. Brenda Leibowitz, Leslie Swartz, Vivienne Bozalek, Ronelle Carolissen, Lindsey Nicholls and Poul Rohleder. HRSC press. http://www.hsrcpress.ac.za/product.php?mode=search\&page=1\& freedownload=1\&productid $=2299$

Bozalek, V., Ronelle Carolissen, Brenda Leibowitz, Lindsey Nicholls, Poul Rohleder and Leslie Swartz. 2010. Engaging with difference in higher education through collaborative inter-institutional pedagogical practices. South African Journal of Higher Education 24(6): 1023-1037.

Chaudry, Lubna Nazir. 2009. Forays into the mist. In Voice in qualitative research, ed. Alecia Youngblood Jackson and Lisa A. Mazzei, 137-164. Milton Park \& New York: Routledge.

Coventry, Michael. 2008. Engaging gender: Student application of theory through digital storytelling. Arts and Humanities in Higher Education 7(2): 205-219. http://doi.org/10.1177/1474022208

Department of Education. 1997. Education White Paper 3: A Programme for the Transformation of Higher Education. Higher Education. Department of Education White Papers. Pretoria: Department of Education. http://www.che.ac.za/documents/d000005/White_Paper3.pdf

Department of Education. 2001. Education White Paper 6: Special Needs Education, Building an Inclusive Education and Training System. Department of Education White Papers. Pretoria: Department of Education. http://www.info.gov.za/whitepapers/2001/educ6.pdf

DiAngelo, Robin. 2011. White fragility. International Journal of Critical Pedagogy 3(3): 54-70.

DuBois, William Edward B. 1903. The souls of Black folk. Oxford: Oxford University Press.

Ford, Maureen. 2004. Considering the standpoints of differently situated others: Teachers and arrogant perception. Philosophy of Education: 337-345.

Freeman, M. 2010. Hindsight: The promise and peril of looking backward. Oxford: Oxford University Press.

Freeth, Rebecca. 2013. Just facilitation: Talking about race, privilege and sustainability. In Proceedings of the 19th International Sustainable Development Conference, 149-162. Stellenbosch: Sustainability Institute. http://www.sustainabilityinstitute.net/newsdocs/document-downloads/ doc_download/640-rebecca-freeth-just-facilitation-talking-about-race-privilege-andsustainability

Gachago, Daniela. 2015. Sentimentality and digital storytelling: Towards a post-conflict pedagogy in pre-service teacher education in South Africa. Unpublished Thesis. School of Education, University of Cape Town. doi:10.13140/RG.2.1.4738.8403.

Gachago, Daniela. 2016. The performativity of digital stories in contexts of systemic inequality. South African Journal for Higher Education 30(3): 296-308.

Gachago, Daniela, Eunice Ivala, Agnes Chigona and Janet Condy. 2015. Owning your emotions or sentimental navel-gazing: Digital storytelling with South African pre-service student educators. Journal of Cultural Science 8(2): 18-35.

Gachago, D. and Asanda Ngoasheng. 2016. South Africa's "Rainbow Nation” is a myth that students need to unlearn. The Conversation, October 19. https://theconversation.com/south-africasrainbow-nation-is-a-myth-that-students-need-to-unlearn-66872

Georgakopoulou, Alexandra. 2006a. The other side of the story: Towards a narrative analysis of narratives-in-interaction. Discourse Studies. doi:10.1177/1461445606061795.

Georgakopoulou, Alexandra. 2006b. Thinking big with small stories in narrative and identity analysis, ed. Michael Bamberg. Narrative Inquiry 16(1): 4-9. Amsterdam and Philadelphia: John Benjamins Publishing Company.

Gobodo-Madikizela, Pumla. 2008. Trauma, forgiveness and the witnessing dance: Making public spaces intimate. The Journal of Analytical Psychology 53(2): 169-88. http://doi.org/10.1111/j.14685922.2008.00715.x

Hodes, Rebecca. 2015. “The Rhodes statue must fall”: UCT’s radical rebirth. Daily Maverick, March 
13. http://www.dailymaverick.co.za/article/2015-03-13-the-rhodes-statue-must-fall-ucts-radicalrebirth/\#.VREevfmUcn4

hooks, bell. 1994. Teaching to transgress - Education as the practice to freedom. New York and London: Routledge.

hooks, bell. 2000. Feminism is for everybody - Passionate politics. Cambridge, MA: South End Press.

Ivits, Shantel. 2009. Disturbing the comfortable: An ethical inquiry into pedagogies of discomfort and crisis. The University of British Columbia (Vancouver).

Jansen, Jonathan. 2004. Race and education after ten years. Perspectives in Education 22(4): 117-128.

Jansen, Jonathan. 2009. Knowledge in the blood: Confronting race and apartheid past. Stanford: Stanford University Press.

Kohler Riessman, Catherine. 2008. Narrative methods for the human sciences. Thousand Oaks, London, New Delhi: Sage Publications.

Lambert, Joe. 2013. Digital storytelling: Capturing lives, creating communities. $4^{\text {th }}$ Edition. New York: Routledge.

Lefko-Everett, Kate. 2012. SA Reconciliation Barometer Survey: 2012 REPORT Youth and Reconciliation in South Africa. Institute for Justice and Reconciliation. http://reconciliationbarometer.org/wp-content/uploads/2012/12/2012-SA-ReconciliationBarometer-FINAL.pdf

Lugones, Maria. 1987. Playfulness, world-travelling, and loving perception. Hypatia 2(2): 3-19.

Mazzei, Lisa A. 2008. Silence speaks: Whiteness revealed in the absence of voice. Teaching and Teacher Education 24(5): 1125-1136. doi:10.1016/j.tate.2007.02.009.

Msimang, Sisonke. 2013. Unfinished business of race and reconciliation in South Africa. Daily Maverick, June 12. http://www.dailymaverick.co.za/opinionista/2013-06-12-our-unfinishedbusiness-race-and-reconciliation/\#.Vcic_fmqpBc

Ngoasheng, Asanda and Daniela Gachago. 2017. Dreaming up a new grid: Two lecturers' reflections on challenging traditional notions of identity and privilege in a South African classroom. Education as Change 21(2): 187-207. https//dio.org/10.17159/1947-9417/2017/2029

Oppermann, Matthias. 2008. Digital storytelling and American Studies: Critical trajectories from the emotional to the epistemological. Arts and Humanities in Higher Education 7(2): 171-187. http://doi.org/10.1177/1474022208

Pattman, Rob. 2010. Investigating "race” and social cohesion at the University of Kwa-Zulu Natal. South African Journal of Higher Education 24(6): 953-71.

Rohleder, Poul, Leslie Swartz, V. Bozalek, Ronelle Carolissen and Brenda Leibowitz. 2008. Community, self and identity: Participatory action research and the creation of a virtual community across two South African universities. Teaching in Higher Education 13(2): 131-143. doi:10.1080/13562510801923187.

Soudien, Crain, Wynoma Michaels, Sankie Mthembi-Mahanyele, Mokubung Nkomo, Gugu Nyanda, Nkateko Nyoka, Sipho Seepe, Olive Shisana and Charles Villa-Vicencio. 2008. Report of the Ministerial Committee on Transformation and Social Cohesion and the Elimination of Discrimination in Public Higher Education Institutions. Pretoria: Department of Education.

Swartz, Leslie, Poul Rohleder, Vivienne G. Bozalek, Ronelle Carolissen, Brenda Leibowitz and Lindsey Nicholls. 2009. "Your mind is the battlefield": South African trainee health workers engage with the past. Social Work Education 28(5): 488-501. doi:10.1080/02615470802129872

Thamm, Marianne. 2014. Cape Town racist club assault: The tragedy and danger of an ahistorical upbringing. Daily Maverick, November 14. http://www.dailymaverick.co.za/opinionista/2014-1127-cape-town-racist-club-assault-the-tragedy-and-danger-of-an-ahistorical-upbringing/\# . VZTrBPmqpBf.

Tronto, Joan. 1993. Moral boundaries: A political argument for an ethic of care. New York \& London: Routledge. 
Young, Iris Marion. 2011. Responsibility for justice. New York: Oxford University Press.

Yuval-Davis, Nira. 2006. Belonging and the politics of belonging. Patterns of Prejudice 40(3): 197214. doi:10.1080/00313220600769331.

Zembylas, Michalinos. 2008. Trauma, justice and the politics of emotion: The violence of sentimentality in education. Discourse: Studies in the Cultural Politics of Education 29(1): 1-17. doi:10.1080/01596300701801278.

Zembylas, Michalinos. 2013. The "crisis of pity" and the radicalization of solidarity: Toward critical pedagogies of compassion. Educational Studies 49(6): 504-521. doi:10.1080/00131946.2013.844148.

Zembylas, Michalinos, Vivienne G. Bozalek and Tammy Shefer. 2014. Tronto’s notion of privileged irresponsibility and the reconceptualisation of care: Implications for critical pedagogies of emotion in higher education. Gender and Education 26(3): 200-214. doi:10.1080/09540253.2014.901718. 